\title{
APPLICATION OF ICT IN THE PROCESS OF PROFESSIONAL DEVELOPMENT OF TEACHERS IN HIGHER AND POSTGRADUATE PEDAGOGICAL EDUCATION INSTITUTIONS
}

\author{
ЗАСТОСУВАННЯ ІКТ У ПРОЦЕСІ ПРОФЕСІЙНОГО \\ РОЗВИТКУ ВЧИТЕЛІВ У ЗАКЛАДАХ ВИЩОЇ ТА ПІСЛЯДИПЛОМНОЇ \\ Oksana VOITOVSKA, \\ Doctor in Education, Assosiate \\ Professor \\ ovoitovskaya@ukr.net \\ http://orcid.org/0000-0002-1814-5895 \\ ПЕДАГОГІЧНОЇ ОСВІТИ \\ Оксана ВОЙТОВСЬКА, \\ доктор педагогічних наук, доцент \\ Національний педагогічний \\ університет \\ імені М. П. Драгоманова \\ Kyiv, 9, Pirogova St., \\ 01601 \\ $\checkmark$ м. Київ, вул. Пирогова, 9, \\ 01601
}

Original manuscript received: February 03, 2021

\section{ABSTRACT}

Revised manuscript accepted: April 15, 2021

The article is based on the analysis of scientific and pedagogical literature determines that the main properties of educational innovations are manifested in systematic changes associated with the transition from the lower quality to higher quality in the organization, monitoring, quality management systems of the educational and scientific process, as well as specific features of mental activity, which is the result of new socio-economic, psychological social processes in the activities and thinking of all its participants. It is noted that the preparation of future teachers for innovation is a long step-by-step process of formation of his personality. It is stated that each institution, as a component of the education system, during the organization and direct implementation of the educational and scientific cognitive process should use the capabilities and capacities of ICT at a sufficient level to solve educational problems - to carry out elearning, which in turn requires the creation and constant development of informatization of the methodical system of institutions of higher and postgraduate pedagogical education. It is established that the modern system of higher and postgraduate pedagogical education has significant experience in the use of ICT in the process of professional development of teachers. Among them, the most recognized and convenient are hypertext technology, the Internet (e-mail, TV-video conferencing, chat, etc.), "virtual reality" and multimedia technology. It is noted that the use of modern information telecommunication networks has significantly changed the communicative environment, opened new ways to search for information, expanded the range of Internet use in various spheres of life. It has been determined that in recent years in different countries special attention has been paid to the possibilities of using computer telecommunication technologies in the organization of education. They provide effective feedback, which involves both the organization of the study material and communication with the teacher when the need arises. Such learning is called distance learning. The 
most important for the educational process services provided by the Internet technology are described: e-mail, TV, and video conferencing, "virtual reality».

Keywords: professional development of teachers, postgraduate pedagogical education, continuing education.

Introduction. Innovations in the field of education are newly created or improved goals, content, forms, and methods of teaching and education, organization of the educational and scientific process of teachers and students. The result of scientific research is the latest technologies, products, or services, as well as organizational and technical solutions of industrial, managerial, business type, which significantly increase the efficiency and effectiveness of the process of education by customers of such services. Thus, the main properties of educational innovations are planned changes associated with the transition from lower quality to higher in the organization, implementation, monitoring, quality management systems of the educational and scientific process, as well as specific features of mental activity resulting from the impact of new social-economic, psychological and social processes in the activities and thinking of all participants: teachers, students, parents, the public, are characterized by continuity and focus on modernizing the existing system.

Purpose and methods are to analyze the main aspects of the use of ICT in the process of professional development of teachers in institutions of higher and postgraduate pedagogical education.

Describe the most important for the educational process services provided by the Internet: e-mail, TV, and video conferencing, «virtual reality».

Analysis of basic research and publications. Scientists point to the use of modern information and communication technologies in education, the formation and development of the educational and scientific environment of higher education institutions based on ICT technology, cloud computing in their works (V. Y. Bykov (2008), L.V. Denysova (2010), M. I. Zhaldak (2005), R.V. Klopov (2010), L. L. Makarenko (2012), T.V. Pidgorna (2012), Y. S. Ramsky (2003), S. M. Yashanov (2017) and other scientists.

Results and discussions. Preparation of the future teacher in higher education institution for innovative activity is a long step-by-step process of formation of his personality. We see the main direction of such training in the formation of professional and pedagogical skills of innovation in professional activities (O. Voitovska, 2013).

Each institution, as a component of the education system, during the organization and direct implementation of the educational and scientific cognitive process must use opportunities and capacities at a level sufficient to solve educational problems of ICT - e-learning, which in turn requires the creation and continuous development of informatization of the methodical system of a higher education institution. This problem is especially acute in modern institutions of higher and postgraduate pedagogical education, as the informatization of the developing methodological system reflects the increasing flexibility of the goals and objectives of the education system in 
general and the electronic educational process in institutions of higher and postgraduate pedagogical education.

The modern system of higher education has considerable experience in the use of ICT in the process of professional development of teachers. Among them, the most recognized and convenient are hypertext technology, the Internet (e-mail, TV-video conferencing, chat, etc.), "virtual reality» and multimedia technology. Let us consider the above technologies in more detail.

A significant step in the history of its development in the early ' 90 s is the informatization of education due to hypertext technology. It opened up new possibilities by creating hypertext in HTML (HyperText Markup Language) invented by Timothy Burnes-Lee. In the educational and scientific process, hypertext, as a separate technology, is rarely used. More often it provides interactivity of software products and integrated technologies.

Internet technology had an important influence on the development of the informatization of education. The use of modern information telecommunication networks has significantly changed the communicative environment, opened new ways to search for information, expanded the range of Internet use in various spheres of life.

The main criterion for assessing the degree of informatization of the educational process is the ability to access the Internet and use for educational purposes such resources and technologies as training and expert systems, database and knowledge base, automated training courses, information retrieval, and information reference systems, automated library systems, electronic journals, video and teleconferences, e-mail; conducting (participation) chats, forums, webinars, Internet conferences, individual and group consultations, etc.

Telecommunications, combined with the Internet, significantly expand the range of users and provide ample opportunities for their use in the educational and scientific process through:

- interactivity and prompt feedback;

- prompt transmission at any distance of information of any kind and volume;

- solving a certain issue through the e-conference system;

- organization of joint telecommunication projects.

In recent years, special attention has been paid in various countries to the use of computer telecommunications technology in the organization of education. They provide effective feedback, which involves both the organization of the study material and communication with the teacher when the need arises. Such distance learning is called distance education. It provides an opportunity to organize a convenient individual training schedule, which would combine the intense rhythm of the main activity with the development of new knowledge. The advantages of distance learning have long been known, but this technique has only recently begun to be actively implemented by domestic free economic zones.

Currently, the following ICTs are increasingly used in higher education institutions: video and teleconferencing, holding (participation) chats, forums, webinars, Internet conferences, individual and group 
consultations, e-mail, e-journals, a new technology of contactless information interaction - «virtual reality», multimedia technology, etc. This has become especially necessary in the current realities of the Covid-2019 pandemic.

Almost all universities and research libraries of Ukraine have communication nodes - separate departments (problem laboratories, information and computer centers, institutes, etc.), which perform the functions of Internet centers. The main tasks of the following units:

- organization of access to information repositories based on the use of local and global networks, in particular, the Internet;

- support of the official university server, cataloging and systematization of electronic textbooks, and information support of the educational process;

- conducting scientific and methodological research on the use of communication technologies in teaching and research;

- creation of a publicly available database of modern software products and teaching aids that can be freely distributed;

- support of educational sites of separate departments, deans' offices, institutes, etc.;

- introduction of TV and video conferences, electronic library catalogs into the training system;

- support of the Web-server of future teachers;

- ensuring the work of training and support staff.

The use of the Internet in ensuring the professional development of teachers in higher and postgraduate pedagogical education puts forward some fundamentally new requirements, the main of which is to provide online work: access to electronic textbooks and university websites, use of electronic translators, databases, and libraries. Standard Internet tools, such as TV and video conferencing, allow direct contact between teacher and students, current control and self-control of knowledge, advice, and more.

Students who use the Internet have the opportunity to:

- develop the technical skills needed by Internet users to communicate and gather information;

- monitor the development of new information technologies;

- learn to synthesize data obtained via the Internet into a single whole;

- learn to use various search engines.

The hardware and software of the Internet are quite convenient for creating educational programs. In particular, the program can be designed as a Web page hosted on a WWW server, and to work with it, the student only needs to be connected to the network.

We describe the most important for the educational process services provided by the Internet: e-mail, TV, and video conferencing, «virtual reality». Furthermore, e-mail allows you to: quickly exchange prepared messages or information stored in advance in computer memory; compactly store information that can be printed at any time; display texts, graphics, and video images on a computer monitor; prepare and edit received and sent text messages; use and transmit computer training programs. 
The above gives reason to believe that e-mail correspondence is an essential means of distance learning, as the teacher has the opportunity to provide students with all kinds of materials before the dialogue part of the class. And during the research work, it allows you to maintain contacts with colleagues around the world, as well as the exchange of publications.

Teleconferencing is one of the services of the Internet, which is similar to e-mail but has some differences. Teleconferences are discussions or group discussions on various topics conducted through the Internet. They are serviced by special servers. Teleconferences are reminiscent of ordinary conferences or seminars, electronic boards where everyone can «speak». Unlike traditional communication, statements on the issues under discussion are recorded, and you can respond to them very quickly with your messages. The essential features of a teleconference are: it is a set of messages from a certain field of knowledge; conferences are organized in groups, and each group has a hierarchical structure; conference materials are stored on special servers and serve as a means of exchanging new messages with each other; participating in conferences, you can read and answer the questions discussed; own messages of participants can be published in conference materials; you can subscribe to any teleconference. This allows you to constantly receive all messages that come to its address. The disadvantage of teleconferencing services is the impossibility of instant communication with recipients. It takes some time to spread new messages of a particular conference, but on the other hand, it allows you to participate in conferences around the clock.

Video conferencing allows two or more people to communicate remotely with each other in real-time. It has become a new form of interactive communication between scientists and teachers, which does not require a mandatory presence in one place or another. This system can be integrated into training programs with minimal adaptation to the proposed course. It was designed to support two-way video and audio communication between multiple addresses. Today, video conferencing has become indispensable in distance education.

In the modern educational and scientific process, a new technology of contactless information interaction - «virtual reality» is increasingly being used. It complements the physical world with digital data provided by computer devices (smartphones, tablets, and AR glasses) in real-time. It is necessary to use a set of multimedia operating environments that create the impression of personal participation in real-time, stereoscopically represented in the "screen world». Multimedia is a modern computer technology that allows you to combine text, sound, video, graphics, and animation in a computer system. This presentation of information does not provide a consistent, as usually happens when working with texts, but the parallel perception of information. With the introduction of this approach, the effectiveness of training increases significantly. Educational computer products are an important component of the process of professional training of teachers in higher education institutions with modern innovative technologies based on information and communication support. In the intersessional period, students in institutions of higher and postgraduate 
pedagogical education can continue their studies, deepen knowledge, skills, competencies, using the possibilities of distance learning with the help of educational computer products (electronic textbooks, computer problems, manuals, hypertext information, and reference systems - archives, catalogs, directories, encyclopedias, testing, and modeling simulators, etc.) that are developed using knowledge from many fields of science-based on multimedia technologies.

Conclusions. Thus, the main aspects of the use of ICT in the process of professional development of teachers in higher and postgraduate pedagogical education institutions were analyzed. ICT technologies used during the professional development of teachers in institutions of higher and postgraduate pedagogical education are characterized, such as video and teleconferences, holding (participation) of chats, forums, webinars, Internet conferences, individual and group consultations, e-mail, electronic magazines, the technology of contactless information interaction - «virtual reality», multimedia technology, etc.

\section{Література}

Денисова Л. В. Гіпермедійне інформаційне середовище навчання як засіб професійної підготовки фахівців з фізичного виховання і спорту : автореф. дис. ...канд. пед. наук. Київ, 2010. 22 с.

Биков В. Ю. Моделі організаційних систем відкритої освіти : монографія. Київ : Атіка, 2008. 684 с.

Жалдак М. І. Про деякі методичні аспекти навчання інформатики в школі та педагогічному університеті. Наукові записки Тернопільського національного університету ім. В. Гнатюка. Серія «Педагогіка». 2005. № 6. С. 17-24.

Клопов Р. В. Професійна підготовка майбутніх фахівців фрізичного виховання і спорту із застосуванням інфоомаційних технологій: теорія і практика: монографрія. Запоріжжя, 2010. 386 с.

Макаренко Л. Л. Роль інформаційно-освітнього середовища в процесі формування інформаційної культури. Наукові записки Національного педагогічного університету ім. М. П. Драгоманова. Сер. : Педагогічні та історичні науки. 2012. Вип. 107. С. 102-117.

Рамський Ю. С. Інфрормаційне суспільство. Інформатизація освіти. Комп'ютерноорієнтовані системи навчання: Зб. наук. праць. К. : НПУ імені М. П. Драгоманова. Вип. 7. 2003. С.16-28.

Підгорна Т. В. Структура інформатичних компетентностей. Науковий часопис НПУ імені М. П. Драгоманова. Серія 2 : Комп'ютерно-орієнтовані системи навчання. 2012. №. 12. С. 109-116.

Яшанов С. М. Теоретичні та методичні проблеми застосування вільно розповсюджуваного програмного забезпечення в інформатичній підготовці майбутнього вчителя. Освітній дискурс. Гуманітарні науки. 2017. Вип.2(1). С. 18-29.

\section{References}

Denysova L. (2010). Hipermediine informatsiine seredovyshche navchannia yak zasib profesiinoi pidhotovky fakhivtsiv z fizychnoho vykhovannia i sportu : avtoref. dys. ...kand. ped. nauk. Kyiv, 22 [in Ukrainian].

Bykov V. (2008). Modeli orhanizatsiinykh system vidkrytoi osvity : monohrafiia. Kyiv : Atika, 684 [in Ukrainian]. 
Zhaldak M. (2005). Pro deiaki metodychni aspekty navchannia informatyky $v$ shkoli ta pedahohichnomu universyteti. Naukovi zapysky Ternopilskoho natsionalnoho universytetu im. V. Hnatiuka. Seriia «Pedahohika». 2005. 6. 17-24 [in Ukrainian].

Klopov R. (2010). Profesiina pidhotovka maibutnikh fakhivtsiv fizychnoho vykhovannia i sportu iz zastosuvanniam informatsiinykh tekhnolohii: teoriia i praktyka: monohrafiia. Zaporizhzhia, 386 [in Ukrainian].

Makarenko L. (2012). Rol informatsiino-osvitnoho seredovyshcha $v$ protsesi formuvannia informatsiinoi kultury. Naukovi zapysky Natsionalnoho pedahohichnoho universytetu im. M. P. Drahomanova. Ser. : Pedahohichni ta istorychni nauky. 2012. 107. 102-117 [in Ukrainian].

Ramskyi Yu. (2003). Informatsiine suspilstvo. Informatyzatsiia osvity. Kompiuternooriientovani systemy navchannia: Zb. nauk. prats. K. : NPU imeni M. P. Drahomanova. 7. 16-28 [in Ukrainian].

Pidhorna T. (2012). Struktura informatychnykh kompetentnostei. Naukovyi chasopys NPU imeni M. P. Drahomanova. Seriia 2 : Kompiuterno-oriientovani systemy navchannia. 12. 109-116 [in Ukrainian].

Yashanov S. (2017). Teoretychni ta metodychni problemy zastosuvannia vilno rozpovsiudzhuvanoho prohramnoho zabezpechennia $v$ informatychnii pidhotovtsi maibutnoho vchytelia. Osvitnii dyskurs. Humanitarni nauky. 2(1). 18-29 [in Ukrainian].

\section{АНОТАЦІЯ}

У статті на основі аналізу науково-педагогічної літератури визначено, що головними властивостями освітніх інновацій є планомірні зміни, пов'язані з переходом із нижчого якісного стану до вищого в організації, здійсненні моніторингу, системах управління якістю освітньо-наукового процесу, а також специфічних особливостях розумової діяльності, що $є$ результатом упливу нових сощіально-економічних, психологічних суспільних процесів у діяльності та мисленні всіх ї̈ учасників. Зазначено, що підготовка майбутнього вчителя до інноваційної діяльності $\epsilon$ тривалим поетапним процесом становлення його особистості. Вказано, що кожний заклад, як складник системи освіти, під час організації та безпосереднього здійснення освітньонаукового пізнавального процесу повинен на достатньому для вирішення освітніх завдань рівні використовувати можливості та потужності IКT - здійснювати електронне навчання (e-learning), що зі свого боку потребує створення та постійного розвитку інформатизації методичної системи закладів вищої та післядипломної педагогічної освіти. Встановлено, що сучасна система вищої та післядипломної педагогічної освіти має значний досвід використання IКТ у процесі профресійного розвитку вчителів. Серед них найбільш визнаними та зручними є: гіпертекстова технологія, Інтернет (електронна пошта, теле-відеоконфреренція, чат тощо), «віртуальна реальність» і технологія мультимедіа. Зазначено, що використання сучасних інформаційних телекомунікаційних мереж суттєво змінило комунікативне середовище, відкрило нові иляхи до пошуку інформаціі, розширило спектр використання Інтернету в різних сфрерах життєдіяльності. Визначено, що останніми роками в різних країнах особлива увага приділялася можливостям використання комп'ютерних телекомунікаційних технологій в організації навчання. Вони забезпечують ефективний зворотній зв'язок, що передбачає як організацію вивчення навчального матеріалу, так і спілкування з викладачем, коли виникає потреба в цьому. Таке навчання на відстані отримало назву дистанційного. Охарактеризовано найбільш значущі для освітнього процесу послуги, що надаються технологією Iнтернет: електронну пошту, теле- івідеоконференціі, «віртуальну реальності».

Ключові слова: профресійний розвиток вчителів, післядипломна педагогічна освіта, неперервна освіта. 